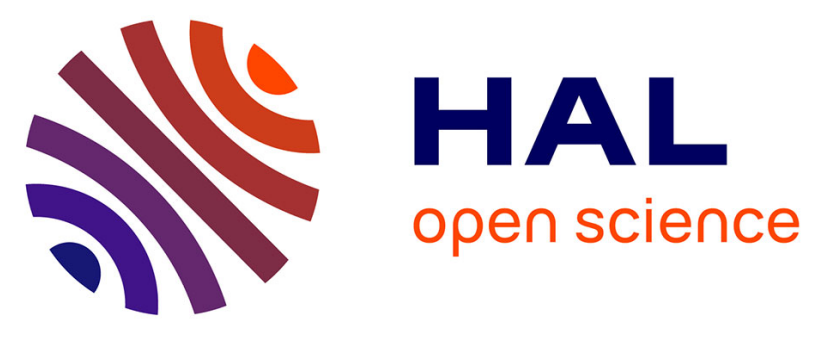

\title{
Impact of generic competition on market share and prices of cardiovascular medicines on the Bulgarian pharmaceutical market
}

Manoela M. Manova, Assena Stoimenova, Fabrice Clerfeuille, Guenka I. Petrova

\section{To cite this version:}

Manoela M. Manova, Assena Stoimenova, Fabrice Clerfeuille, Guenka I. Petrova. Impact of generic competition on market share and prices of cardiovascular medicines on the Bulgarian pharmaceutical market. Journal of Public Health, 2010, 19 (1), pp.91-100. 10.1007/s10389-010-0352-8 . hal00561309

\section{HAL Id: hal-00561309 \\ https://hal.science/hal-00561309}

Submitted on 1 Feb 2011

HAL is a multi-disciplinary open access archive for the deposit and dissemination of scientific research documents, whether they are published or not. The documents may come from teaching and research institutions in France or abroad, or from public or private research centers.
L'archive ouverte pluridisciplinaire HAL, est destinée au dépôt et à la diffusion de documents scientifiques de niveau recherche, publiés ou non, émanant des établissements d'enseignement et de recherche français ou étrangers, des laboratoires publics ou privés. 
Editorial Manager(tm) for Journal of Public Health

Manuscript Draft

Manuscript Number: JOPH-D-10-00005R2

Title: IMPACT OF THE GENERIC COMPETITION ON MARKET SHARE AND PRICES OF CARDIOVASCULAR MEDICINES ON THE BULGARIAN PHARMACEUTICAL MARKET

Article Type: Original Article

Corresponding Author: Mrs Manoela Manova, M.Sc.

Corresponding Author's Institution: Faculty of pharmacy

First Author: Manoela Manova, M.Sc.

Order of Authors: Manoela Manova, M.Sc.; Assena Stoimenova, Ph. D.; Fabrice Clerfeuille, Prof. D. Sc.; Guenka Petrova, Prof. D. Sc.

Abstract: Background

During the last three decades a tremendous progress has been made in the discovery and development of a lot of new molecules in many pharmaceutical areas. These families of real innovative treatment comprise of "originator" molecules (first molecule released, which can be under patent or with expired patent), as well "generic" version of those originator molecules, whose patent has expired. Usually the patent expires 15 to 20 years after the creation of the originator molecule.

Main objective

This research focuses on the effects of the arrival of generic and or therapeutic competitors on the market, in terms of impacts on the market share and prices.

Methodology

Between 2005 and 2007 we follow three classes of medicinal products in the cardiovascular area:ACE inhibitors, sartans and statins. They have been studied on the Bulgarian market because there is no regulation in the country stimulating the generic market. The official database of the Bulgarian Health Insurance Fund was used to test our two hypothesis concerning the impact of the generics on market share and prices. To test our hypothesis a t-test analysis, Kolmogorov Smirnov, one and two way ANOVA analyses were performed.

Results

Our results confirm that the generic competition, in general, changes the market. These changes decrease the medicines prices.

The generic competition is not regulatory supported in the country and this fact could influence negatively our study because it does not correspond to the world tendencies.

Furthermore our results confirm that the creation of sustainable generic pharmaceutical market requires active regulatory and marketing measures at all levels including incentives for manufactures, physicians and dispensers.

Key words:

pharmaceutical market - generics - competitors - market share - prices

Response to Reviewers: Reviewer \#1: Comment on the paper "Impact of competition on usage and prices of cardiovascular medicines on the Bulgarian pharmaceutical market" Journal of Public Health 
The authors have not implemented all recommendations.

Some few remarks are the following:

Methodology

It is necessary to use the DDD (defined daily dose) system because it is the gold standard for international drug utilization research. The current results are burdened with bias. DDD describes a technical measurement and comparison unit. Compared with other measurement units, like the usage in $\mathrm{mg}$ for INN, the DDD has the advantage, that changes in the package size or dosage can not distort the measured consumption. Defined daily doses (DDDs) are a WHO statistical measure of drug consumption. Please calculate the DDDs for the studied drugs and then the outcome will be pharmaceutically correct and more therapeutically compatible.

Dear Mr. Reviewer,

As we answer in our previous correspondence the calculations using the DDD methodology are already in a process of analysis but some of the authors included in this manuscript are not participating within the other calculations and analysis, as well as some new colleagues have been included. We consider that it is not ethical to change now the teams during the evaluation process.

We know the WHO methodology and it is really the gold standard, but we also found lots of articles using the approach of measuring the utilization in units of active ingredients, and especially in milligrams.

The comments for the reasoning of such an approach are added in the discussion section, as follows also and below:

Comment is added in the discussion section as follows: Comparison of the market share and prices in milligrams has its own reasoning for international market tender purposes (Al-Abbadi 2009; Karam R. 2010; Zaheer 2007), as well as for reference prices comparison.

Such a price comparison per milligram of active substance is also regularly performed by the Management science for health and World health organisation when they publish the International Drug Price Indicator Guide and all prices are shown per milligrams of active substance (Frye 2007). Some countries are using the generics' price per milligrams in the process of establishment of the lowest price per product within the reimbursement system (Mrazek 2002).

Other authors consider (WHO 2003) that, if medicines utilization is given in terms of grams of active ingredients, drugs with low potency will account for a larger fraction of the total than drugs with high potency, and that the combined products may also change their market figure. In our study we did not observe any combination so our figures could not be affected by such an utilization data. We also did not observe significant changes in the prices per milligram for the medicines with different potency, thus this is not also the case for consideration.

The international prices comparison per milligrams of active substance could be used by the regulatory authorities. Grootendorst (2001) analysed the impact of referenced - based pricing on nitrates usage and cost reduction by using also the cost per milligram. Similar approach was found useful in case of comparison of the medicines prices for particular therapeutic groups (Wang 2008), which is also the case in our study.

Introduction Line 9: Please correct ".such as Angiotensin-Converting Enzyme (ACE inhibitors)." to "such as inhibitors of Angiotensin-Converting Enzyme (ACE inhibitors).".- it is done Line 13: The point is missing. - it is done Line 27: Please remove the word "new" from sentence "To give an example, a new molecule, the ramipril,." because ramipril is an already known ACE inhibitor. - it is done 
Line 6: Please give the bibliographical reference for "... and from some of them more than a thousand generic products have originated." . It is changed to: "lots of generic products have originated" (reference added Rossy (Ed)

Line 23: Please correct ".influencing the generic medicines market." to ".influencing the generic medicine market.". It is changed

Main objective

Line 33: Considering grammar you should write "The aim of this study was to analyse.". Agree and corrected

Methods

Line 14: Please delete "Appendix 1" because the statement of this sentence is not presented in this appendix. Done

Please take the same spelling for the word "mg" in the whole article. Corrected

Line 45: Please delete "Furthermore" because two following sentences have the same beginning. Done Line 2: These two sentences are inconsistent: "In the group of sartans generic competitors were available only for losartan." (line 2, page 10), "Within the group of sartans, valsartan and losartan have expired patents and generics available on the market"(line 17, page 8). Please check this. Checked and removed

Line 2: "In the group of sartans generic competitors were available only for losartan.": Please write "In the group of sartans generic competitors were only available for losartan.". Changed

Results

Line 12: Please correct "ACE Inhibitors" to "ACE inhibitors" and take the same spelling in the whole article. Done

Line 14: Please write ".and the generics for ramipril.". Done

Line 16: These two sentences are inconsistent: "In the therapeutic class of statins we also found 4 INNs with generics: the simvastatin, pravastatin, atorvastatin and the lovastatin." (line 16, page 10), "The statins therapeutic group is composed of 6 molecules from which 3 have expired patent." (line 24, page 8). Please check this. Done

Analysis of the market share of products

Line 26: Considering grammar you should write ".when we begun our study." instead of ".when we begin our study.". Corrected

Line 1: Please correct ".after the introduction of the generic competitor to lisinopril in 2006 " to ".after the introduction of the generic competitors to lisinopril in 2006". Corrected

Line 46: Please write ". in market share of the belonging INNs". Corrected

Line 52: Please take the same spelling for the word "National health insurance fund".

Table 4 and Appendix 1 Corrected

Considering the word "BGL" you should write "BGN" because the ISO 4217 currency code for the new Bulgarian lev is BGN Corrected.

Reviewer \#2: The major limitation of the study is still that the ATC/DDD system was not used. http://www.whocc.no/filearchive/publications/drug_utilization_research.pdf Dear Mr. Reviewer,

As we answer in our previous correspondence the calculations using the DDD methodology are already in a process of analysis but some of the authors included in this manuscript are not participating within the other calculations and analysis, as well as some new colleagues have been included. We consider that it is not ethical to change now the teams during the evaluation process. 
We know the WHO methodology and it is really the gold standard, but we also found lots of articles using the approach of measuring the utilization in units of active ingredients, and especially in milligrams.

The comments for the reasoning of such an approach are added in the discussion section, as follows also and below:

Comparison of the market share and prices in milligrams has its own reasoning for international market tender purposes (Al-Abbadi 2009; Karam R. 2010; Zaheer 2007), as well as for reference prices comparison.

Such a price comparison per milligram of active substance is also regularly performed by the Management science for health and World health organisation when they publish the International Drug Price Indicator Guide and all prices are shown per milligrams of active substance (Frye 2007). Some countries are using the generics' price per milligrams in the process of establishment of the lowest price per product within the reimbursement system (Mrazek 2002).

Other authors consider (WHO 2003) that, if medicines utilization is given in terms of grams of active ingredients, drugs with low potency will account for a larger fraction of the total than drugs with high potency, and that the combined products may also change their market figure. In our study we did not observe any combination so our figures could not be affected by such an utilization data. We also did not observe significant changes in the prices per milligram for the medicines with different potency, thus this is not also the case for consideration.

The international prices comparison per milligrams of active substance could be used by the regulatory authorities. Grootendorst (2001) analysed the impact of referenced - based pricing on nitrates usage and cost reduction by using also the cost per milligram. Similar approach was found useful in case of comparison of the medicines prices for particular therapeutic groups (Wang 2008), which is also the case in our study. 
Manova M. Manoela*

Assistant Professor, M. Pharm

Department of Organisation and Economy of Pharmacy, Medical University in Sofia, Faculty of Pharmacy

2 Dunav Str ., 1000 Sofia, Bulgaria

Tel: +35929236589

mob: + 359888223 101;

fax: +35929879874

manoela_manova@yahoo.com

Assena Stoimenova

Assistant Professor, Ph. D. Department of Organisation and Economy of Pharmacy, Medical University in Sofia, Faculty of Pharmacy, 2 Dunav Str ., 1000 Sofia, Bulgaria

Tel: ++3592 9236589; assena_stoimenova@yahoo.com

Fabrice Clerfeuille

Professor of Marketing, D. Sc. University of Nantes, IEMN-IAE, Chemin de la Censive du Tertre, BP 52231, 44322 Nantes Cedex 3, France

Tel: + 33661198 752; fabrice.clerfeuille@ univ-nantes.fr

Guenka I. Petrova

Professor of Social Pharmacy and Pharmacoeconomics; D. Sc. Medical University in Sofia, Faculty of Pharmacy, 2 Dunav Str ., 1000 Sofia, Bulgaria

tel: + 359884222 964; gpetrova@ pharmfac.net

* Corresponding author 


\section{Introduction}

During the last three decades a tremendous progress has been made in the discovery and development of a lot of new molecules in many pharmaceutical areas. The therapeutic groups of cardiovascular medicines, such as inhibitors of Angiotensin-Converting Enzyme (ACE inhibitors), sartans and statins, are good examples of the aforementioned development and creation of therapeutic families (Fyhrquist and Saijonmaa 2008; Raizada and Ferreira 2007).

These families of real innovative treatment comprise of "originator" molecules (first molecule released, which can be under patent or with expired patent), as well "generic" version of those originator molecules, whose patent has expired. Usually the patent expires 15 to 20 years after the creation of the originator molecule. These last products (what we call "generics") have the same chemical structure and have been proven to be essentially similar in bioavailability (Morgan et al. 2005).

To give an example, a molecule, the ramipril, in the family of ACE inhibitors has been launched by the pharmaceutical laboratory SANOFI AVENTIS under the name of Triatec ${ }^{\circledR}$. When the patent of this product has expired, a competitor, the pharmaceutical laboratory QUALIMED launched the same product in terms of molecule and effects, so, a generic, called Ramipril Qualimed ${ }^{\circledR}$. However, within the same therapeutic group, MSD had already launched enalapril under the name of Renitec ${ }^{\circledR}$ that is a "therapeutic competitor", possessing small variation in the chemical structure. Following the same approach of modification of the first molecule the perindopril, trandolapril, fosinopril and so on were later developed and thus the whole therapeutic family started to expand.

\section{Conceptual framework and Literature review}

The generics create competition and drive medicine prices down (Lee 2004). Many studies show in fact that when a new medicinal product (a new molecule giving an originator or the same molecule giving a generic) appears on the pharmaceutical market, it affects the market patterns as well as prices of the existing generic and/or therapeutic competitors (Dirach 2000). To what extent and for how long time it happens depends on the specific characteristics of the national market, the laws concerning the generics and the pharmaceutical companies' policy. 
A common perception is that the original medicinal product ensures new therapeutic options provision and contribute to the maintaining of control over the pharmaceutical expenditure (Fiona 1997).

Some countries use laws to promote the prescription and the delivery of generics, which leads to a decrease in the health expenditures. Studies focusing on the market policy of the pharmaceutical manufacturers consider that every new product, within the same therapeutic class, is characterised by simultaneous entry of competitors rather than sequential (Fiona 1997). Basically, what this means is that the expiration of a product patent is accompanied by the simultaneous entry, sometimes the same day, of a different generic. Models have been created to calculate the aggregated demand and supply features, influencing the generic medicine market (Gascon et al. 2007).

During the last two decades a reference pricing approach was developed, which began to be used in a lot of European countries (Huttin 2002). The reference prices are established after an international or national comparison of prices of the generic or therapeutic alternatives (Mestre 2003). The reference price could be either the lowest or the average price within the compared group of products (Mrazek 2002). This policy stimulates research in the area of price comparison and analysis of the factors influencing price changes, as are the generics' policy and competition.

The cardiovascular medicines are of a particular interest for studying the competition between originators and generics. They are one of the leading therapeutic classes on the global medicine market today, with more or less $10 \%$ of the market sales in value (WHO 2007). For this particular reason, this class presents a big interest for the pharmaceutical manufacturers and we can currently find new innovative products and new generics. This interest is also shared by the health authorities, which want to control the increasing expenditures, analysing their prescription and their usage and creating national rules for price control.

In this cardiovascular category of treatment, three groups of therapeutics present a bigger interest due to the presence of innovative molecules and the arrival of generics: the families of inhibitors of Angiotensin-Converting Enzyme (ACE inhibitors), sartans and statins (drugs.com 2008; Luno et al. 2005; Rossi et al 2006; Levy 2005). 
The ACE inhibitors appeared with the discovery of the captopril molecule in 1975 that was

\section{Hypothesis tested}

Due to the fact that there is no law regulation on the generic medicines in Bulgaria, we want to test two hypotheses:

Hypothesis 1: The introduction of new medicinal products (originators or generics) affects the sales data and/or market share within the group.

Hypothesis 2: The introduction of new medicinal products (originators or generics) decreases the prices of the competitors within the group. 


\section{Methods}

Using the official National Health Insurance Fund's database, we collected information for the prescription of 20 different INN in the cardiovascular classes of medicines: 9 ACE inhibitors, 5 sartans and 6 statins, authorized for sale on the Bulgarian market in the years 2005-2007.

A database was created, which included the prescribed packages of different trade names and dosage forms of medicinal products, sold under the observed 20 International Nonproprietary Names (INN). To summarise the differences between the packages, the usage was recalculated in milligrams for every INN during the particular year observed.

The information for the drug prices was gathered from the official register of the Ministry of Health for all authorised trade names of observed medicines (Ministry of health 2005, 2006, 2007). Then, the prices were recalculated, to establish the price per milligram for every dosage form and within the group of products under the same INN. To calculate the mean price per INN and per milligram a descriptive statistic was applied.

To test the first hypothesis we first applied the Kolmogorov Smirnov (K-S) test towards the sales data during the observed years. The K-S test seeks differences between the distribution function of sales data in 2006 in comparison with 2005, and 2007 in comparison with 2006. The test provides information for the differences between the observed years by rejecting the null hypothesis if no differences exist.

To analyse the possible differences among the sales data of particular INNs during the observed years, the market share of every INN, out of all sold milligrams of INNs within every therapeutic group, was recalculated. Furthermore, in a second step, we calculated the proportions, using the z-test analysis for every INN assuming 95\% CI for the changes in proportions of INNs, comparing the data for the year 2005 versus the year 2006 and the year 2006 versus the year 2007. The z-test provides information for the statistically significant differences among the proportions of INNs sold during the years 2005, 2006 and 2007.

To test the second hypothesis, we first performed a two-way ANOVA analysis to evaluate the statistically significant differences between the prices of active substances, per milligram, for the products within each therapeutic group and during the observed years. If there was a 
difference established we next perform a one way ANOVA analysis to evaluate them per INNs and among the therapeutic alternatives.

\section{Results}

Out of all collected medicinal products in the therapeutic class of ACE inhibitors, we found 3 INNs with generics: the enalapril, lisinopril (during 2005-2007) and the generics for ramipril appears during the third year of observation (2007). In the therapeutic class of statins we also found 4 INNs with generics: the simvastatin, pravastatin, atorvastatin and the lovastatin. In the last therapeutic class studied, the sartans, we found 1 INN with a generic, the losartan. The other INNs within these three therapeutic groups are considered as therapeutic competitors. All these results are in Appendix 1. Some of the fields in Appendix 1 are marked with "0" due to the lack of sales data in the National Health Insurance Fund's database for the particular year observed.

\section{Analysis of the market share of products}

In the product class of ACE inhibitors, the enalapril in milligrams is the leader of the class with $93.1 \%$ of the market share in 2005 - when we begun our study. It's not possible to see it in this appendix but the enalapril permanently increased its' market share in the years before 2005. The market share of enalapril decreased in 2006 (88.6\%), and 2007 (86.34\%) despite the introduction of new generics in 2006.

All other products within the group, except the quinapril (which decreased in 2007 versus 2006) perform a steady increase in their usage, measured in $\mathrm{kg}$, of active substance sold (Appendix 1).

We can say that the fast growth rate of the therapeutic group and introduction of 2 different new molecules within the class lead to a decrease in the market share of enalapril during 2006 with 4,5\% and during 2007 with 2,24\% (Figure 1). On the other hand, the market share of the therapeutic competitors slowly and permanently increases every year thus taking part of the enalapril market share. 
It is also necessary to point out that after the introduction of the generic competitors to lisinopril in 2006, its market share increase with a bigger percentage (from $2.34 \%$ in 2005 to $3.65 \%$ in 2006) than the share of the other therapeutic competitors within the group and this increase continued still, even after the exclusion of one of the products during the next year.

Placed Here - Figure 1: Relative Market Share of ACE inhibitors sales during 2005, 2006 and 2007.

In the product class of sartans, the biggest market share in 2005 was that of telmisartan, probably because of the promotional price of the originator. In the second year the only one product with a generic version (losartan) increased its market share almost 6 times, thus taking a leading position in the group.

The market dynamic in proportions of INNs sold within the group of sartans is mostly evident in comparison with the previous group, but we can suppose that these changes are contributed mainly to the active market development of the products within the group.

Placed here - Figure 2: Relative Market Share of sartans sales during 2005, 2006 and 2007.

The product class of statins is the most dynamic in terms of changes of generic and therapeutic competitors. In this group, we observed that after the increase of the number of generic competitors under the same INN, the relative market share of the INN increased - as is the case for simvastatin. We can consider that the introduction of new generics did not deprive the sales data of the originator immediately, but, in general, contributed to the accumulation in market share of the belonging INNs. In this group we also observed that the introduction of a new product affects the sales data of competitors, as is the case with the inclusion of rosuvastatin.

Placed here - Figure 3: Relative Market Share of statins sales during 2005, 2006 and 2007. 
After applying the Kolmogorov Smirnov test, we observed that there is a statistically significant difference among the sales data during 2006 and 2005, as well as during 2007 and 2006 (Table 1). The test confirmed that the sales data of the observed therapeutic groups changed statistically significantly during the analysed years.

Placed here - Table 1: Results of the Kolmogorov Smirnov test

To test the differences among the INNs' sales data, the z-test analysis was applied. The results of the z-test analysis confirm that for almost all the products, except for the perindopril and trandolapril in the class of ACE inhibitors, and irbesartan from class of sartans, the changes in the market share are statistically significant (Table 2). For all of these three products there is no generic competitor. So we can conclude that the introduction of generics changes the market share of the INNs and contributes to the changes in the share of the therapeutic groups. The changes in the market share products without generics could be explained with the marketing policy of the companies - a fact that was not explored in this study.

Thus our first hypothesis is confirmed.

Placed here - Table 2. Results of the z-test analysis

\section{Analysis of the price changes}

Concerning the prices, all of them decreased during the observed period from 2005 to 2007 but it was mainly due to the changes in the regulation (Appendix 1) (Ministry of health, Drug price registry $2005,2006,2007)$. The regulatory changes affect mainly the decrease of the distributors' margins (wholesale and retail), almost half for the medicines paid by the National Health Insurance Fund.

For the group of ACE inhibitors, the two way ANOVA analysis confirms that the prices per milligram differed among the observed products $(\mathrm{p}<0.05)$, but did not differ statistically significant during the years for the whole group ( $>>0.05$ ) (Table 3). Multiple comparison 


\section{Discussion, limitations and further research}

The cardiovascular medicine market characteristics are of importance for the national markets for a lot of reasons, for example: their permanently growing usage, progress in new molecules discovery, changes in life expectancy of the population, creation of the national rules for price control, and cost containment measures. 
We do observe a dynamic national market of cardiovascular medicines that correspond to the the generic ones (drugs.com. 2008).

Our results confirm those of similar studies - that the generic competition, in general, changes the market in the observed country. These changes benefit the generic products and decrease the medicines' prices.

The generic competition is not regulatory supported in the country and this fact could influence negatively our study because it does not correspond to the world tendencies (Law on Medicinal products for human medicine 2007; Ministry of health 2005, 2006, 2007).

Furthermore, our results confirm some other publications - that the creation of a sustainable generic pharmaceutical market requires active regulatory and marketing measures at all levels, including incentives for manufactures, physicians, and dispensers (Simoens and de Coster 2006; Adriaen et al 2008). It is not only sufficient to shorten the marketing authorisation process for generic medicines at a European level, but every country should perform its own measures as well.

Our study possesses some limitations in terms of the fact that we compare the mean prices per milligram and not per Defined Daily Dose (DDD), which is more therapeutically compatible. Despite the fact that DDD is established in milligrams for most of the medicines, we consider that in the future such analysis should be done for the changes in prices per DDD. Comparison of the market share and prices in milligrams has its own reasoning for international market tender purposes (Al-Abbadi 2009; Karam R. 2010; Zaheer 2007), as well as for reference prices comparison.

Such a price comparison per milligram of active substance is also regularly performed by the Management science for health and World health organisation when they publish the International Drug Price Indicator Guide and all prices are shown per milligrams of active substance (Frye 2007).

Some countries are using the generics' price per milligrams in the process of establishment of the lowest price per product within the reimbursement system (Mrazek 2002).

Other authors consider (WHO 2003) that, if medicines utilization is given in terms of grams of active ingredients, drugs with low potency will account for a larger fraction of the total 
than drugs with high potency, and that the combined products may also change their market figure. In our study we did not observe any combination so our figures could not be affected by such an utilization data. We also did not observe significant changes in the prices per milligram for the medicines with different potency, thus this is not also the case for consideration.

The international prices comparison per milligrams of active substance could be used by the regulatory authorities. Grootendorst (2001) analysed the impact of referenced - based pricing on nitrates usage and cost reduction by using also the cost per milligram. Similar approach was found useful in case of comparison of the medicines prices for particular therapeutic groups (Wang 2008), which is also the case in our study.

The fact that we could not establish strong evidences supporting our second hypothesis could be explained with the short period of observation and slow entrance of generic medicines in the positive drug list of the National Health Insurance Fund.

Generic competitors were found for only 8 out of 20 compared INNs and for 4 of them (ramipril, pravastatin, atorvastatin, losartan) only one competitor that limits the evaluation of the impact of generic competition on prices existed. We didn't analyse the way the pharmaceutical laboratories communicate with the prescribers, which can also have an effect on the market.

Further studies should be organised to evaluate the changes in prices during a longer period, when more generic competitors will be available in the country. The national generic medicines policy is also of importance as it stimulates the medicines' prices competition.

\section{Conclusion}

There are two main conclusions from our study. The first one is that for the therapeutic groups, which include a lot of similar molecules, it is important to consider the competition between the molecules and not only the generic entrance. Originating pharmaceutical companies seem to compete among themselves at a therapeutic level and with generic companies at a price level. 
The second conclusion is that the introduction of generic medicines did not affect the mean

\section{Conflict of interest}

The authors confirm that there are no relevant associations that might pose a conflict of interest.

\section{Bibliography}

Adriaen M, De Witte K, Simoens S (2008) Pricing strategies of originator and generic medicines following patent expiry in Belgium. J Generic Med 5: 175-187, DOI:10.1057/jgm.2008.8

Al-Abbadi I. et al. (2009) One-year assessment of joint procurement of pharmaceuticals in the Public health sector in Jordan. Clin Therapeutics 6 (31): 1335 - 1343, DOI: 10.1016/j.clinthera.2009.05.021

Dirach J (2000) New safe medicines faster: A new concept for drug development. EUFEPS 27 Feb:1-5

http://newmedfaster.com/Attachments/New\%20Safe\%20Medicines\%20Faster_Backgrounder_v3.pdf (Accessed May 2010)

EU (2004) Directive 2001/83 of the European parliament and of the council of 6 November 2001 and on the community code relating to medicinal products for human use. Official Journal of the European Union L-311: 67 - 128

Frye JE (2007) International drug price indicator guide. MSH, Cambridge USA 
Fyhrquist F, Saijonmaa O (2008) Renin-angiotensin system revisited. J Intern Med 264 (3): 224-36, DOI: 10.1111/j.1365-2796.2008.01981.x

Gascon F, De la Fuente D, Puente J, Lozano J (2007) On macroeconomic characteristics of pharmaceutical generics and the potential for manufacturing and consumption under fuzzy conditions. Artificial Intell in medicines 41: 223-235, DOI: 10.1016/j.artmed.2007.07.001 http://www.drugs.com. Accessed March 2008

Grootendorst PV, Dolovich LR, O'Brien BJ, Holbrook AM, Levy AR (2001) Impact of reference-based pricing of nitrates on the use and costs of anti-anginal drugs. CMAJ, 16; 165 (8): 1011-1019

Huttin C (2002) Experiences with reference pricing. Int J Risk Saf Med 15: 85-91

Karam R (2010) Survey report - Prices of medicines in Lebanon. World Health Organization - Health Action International Project on Medicine Prices.

http://www.haiweb.org/medicineprices/surveys/200402LB/survey_report.pdf (Accessed 9

May 2010)

Lee TH (2004) "Me-too" products -- friend or foe? N Engl J Med 350: 211 - 212, DOI: 10.1056/NEJMp038215

Levy BI (2005) How to explain the differences between renin angiotensin system modulators. Am. J. Hyperten 18: 134 S - 141 S, DOI: 10.1016/j.amjhyper.2005.05.005

Luno J, Praga M, de Vinuesa S (2005) The reno-protective effect of the dual blockade of the renin angiotensin system (RAS). Curr Pharm Des 11 (10): 1291 - 3000

Mestre - Ferrandiz J (2003) Reference prices and generic medicines: What can we expect? J Generic Med 1: 31-38 DOI:10.1057/palgrave.jgm.4940015

Ministry of health. Drug price registry. www.mh.government.bg. Assessed 2005, 2006, and 2007 
Morgan S, Kenneth G, Bassett L, Wright J, Evans R, Barer M, Caetano P, Black C (2005)

"Breakthrough "drugs and growth in expenditure on prescription drugs in Canada, BMJ 331

(8) : 815-16, DOI: 10.1136/bmj.38582.703866.AE

Mrazek M (2002) Comparative approaches to pharmaceutical price regulation in the European Union. Croat Med Journal 43 (4): 453-61

National Peoples Assembly. Law on Medicinal products for human medicine. Gov. Newspaper April 2007

National Economic research Associate (2009) Policy Relating to Generic Medicines in the OECD.http://ec.europa.eu/enterprise/pharmaceuticals/pharmacos/docs/nerareport. (Accesed August 2009)

Raizada M, Ferreira A (2007) ACE 2: a new target for cardiovascular disease therapeutics. J Cardiovasc Pharmacol 50 (2): 112 - 9, DOI: 10.1097/FJC.0b013e3180986219

Rossi S (Ed) (2006) Australian Medicines Handbook 2006. Adelaide: Australian Medicines Handbook. ISBN 0-9757919-2-3

Rossi S (Ed.) (2009). Australian Medicines Handbook 2008. Adelaide: Australian Medicines Handbook. ISBN 978-0-9757919-9-8

Scott Morton F (1997) Entry Decisions in the Generic Pharmaceutical Industry, in: National Bureau of Economic Research Working Paper Series, No. 6190, Cambridge: p. 8

Simoens S, de Coster S (2006) Sustainable generic medicines market in Europe. J Generic Med 3 (4): 257 - 68, DOI:10.1057/palgrave.jgm.4950040

Stossel TP. The Discovery of Statins. Cell 2008; 6 (134): 903-905, doi:10.1016/j.cell.2008.09.008

Wang PS, Patrick AR, Dormuth CR, Avorn J, Maclure M, Canning CF, Schneeweiss S (2008). The Impact of Cost Sharing on Antidepressant Use Among Older Adults in British Columbia. Psychiatric Services 59:377-383, doi: 10.1176/appi.ps.59.4.377 
WHO (2003). Introduction to drug utilization research. World Health Organization, Oslo 2003; ISBN 924156234 X

World Health Organisation (2007) The world medicines situation. (WHO/EDM/PAR/2004.5) Geneva, p. 39

Zaheer UDB, Mohamed IMI, Singh H, Bukahri NI, Creese A (2007). Evaluating Drug Prices, Availability, Affordability, and Price Components: Implications for Access to Drugs in Malaysia. PLoS Medicines (4):3; e82. doi:10.1371/journal.pmed.0040082.t00 
Table 1: Results of the Kolmogorov Smirnov test

\begin{tabular}{|c|c|c|c|c|c|}
\hline INN & $\begin{array}{l}\text { Sales data } \\
\text { (mg) } \\
2005 \\
\end{array}$ & $\begin{array}{l}\text { Sales data } \\
\text { (mg) } \\
2006 \\
\end{array}$ & $\begin{array}{l}\text { Sales data } \\
\text { (mg) } \\
2007 \\
\end{array}$ & $\begin{array}{l}\text { K-S } \\
2006 / 2005\end{array}$ & K-S 2007/2006 \\
\hline enalapril & 1906795530 & 2287185280 & 2362110040 & \multirow{9}{*}{$\begin{array}{r}\text { Null } \\
\text { hypothesis } \\
\text { rejected } \\
\end{array}$} & \multirow{9}{*}{$\begin{array}{r}\text { Null } \\
\text { hypothesis } \\
\text { rejected }\end{array}$} \\
\hline lisinopril & 47860510 & 94173850 & 154909420 & & \\
\hline perindopril & 14378880 & 19729440 & 23778840 & & \\
\hline ramipril & 5880420 & 29455406 & 55117400 & & \\
\hline quinapril & 47253900 & 96471300 & 68185500 & & \\
\hline fosinopril & 23618840 & 47761840 & 56553000 & & \\
\hline trandolapril & 3322444 & 6061288 & 7445446 & & \\
\hline cilasapril & & 553630 & 3979220 & & \\
\hline benazepril & & 692160 & 3899840 & & \\
\hline INN & $\begin{array}{l}\text { Sales data } \\
\text { (mg) } \\
2005 \\
\end{array}$ & $\begin{array}{l}\text { Sales data } \\
\text { (mg) } \\
2006 \\
\end{array}$ & $\begin{array}{l}\text { Sales data } \\
\text { (mg) } \\
2007 \\
\end{array}$ & \begin{tabular}{|l|} 
K-S \\
$2006 / 2005$ \\
\end{tabular} & K-S 2007/2006 \\
\hline simvastatin & 13140540 & 26303860 & 125098060 & \multirow{6}{*}{$\begin{array}{r}\text { Null } \\
\text { hypothesis } \\
\text { rejected } \\
\end{array}$} & \multirow{6}{*}{$\begin{array}{r}\text { Null } \\
\text { hypothesis } \\
\text { rejected }\end{array}$} \\
\hline lovastatin & 199510800 & 310969800 & 300126000 & & \\
\hline pravastatin & 5301900 & 9335100 & 12384300 & & \\
\hline fluvastatin & 81453120 & 84938560 & 68862080 & & \\
\hline atorvastatin & 16486500 & 31483800 & 36445200 & & \\
\hline rosuvastatin & & 157360 & 4523400 & & \\
\hline INN & $\begin{array}{l}\text { Sales data } \\
\text { (mg) } \\
2005\end{array}$ & $\begin{array}{l}\text { Sales data } \\
\text { (mg) } \\
2006\end{array}$ & $\begin{array}{l}\text { Sales data } \\
\text { (mg) } \\
2007 \\
\end{array}$ & \begin{tabular}{|l|} 
K-S \\
$2006 / 2005$
\end{tabular} & K-S 2007/2006 \\
\hline losartan & 15715000 & 196378000 & 485893800 & \multirow{5}{*}{$\begin{array}{r}\text { Null } \\
\text { hypothesis } \\
\text { rejected }\end{array}$} & \multirow{5}{*}{$\begin{array}{r}\text { Null } \\
\text { hypothesis } \\
\text { rejected }\end{array}$} \\
\hline valsartan & 58464000 & 70936320 & 68051200 & & \\
\hline telmisartan & 169261120 & 225245440 & 207121600 & & \\
\hline irbesartan & 231000 & 252000 & 0 & & \\
\hline eprosartan & 28089600 & 143152800 & 131695200 & & \\
\hline
\end{tabular}


Table 2: Results of the z-test analysis

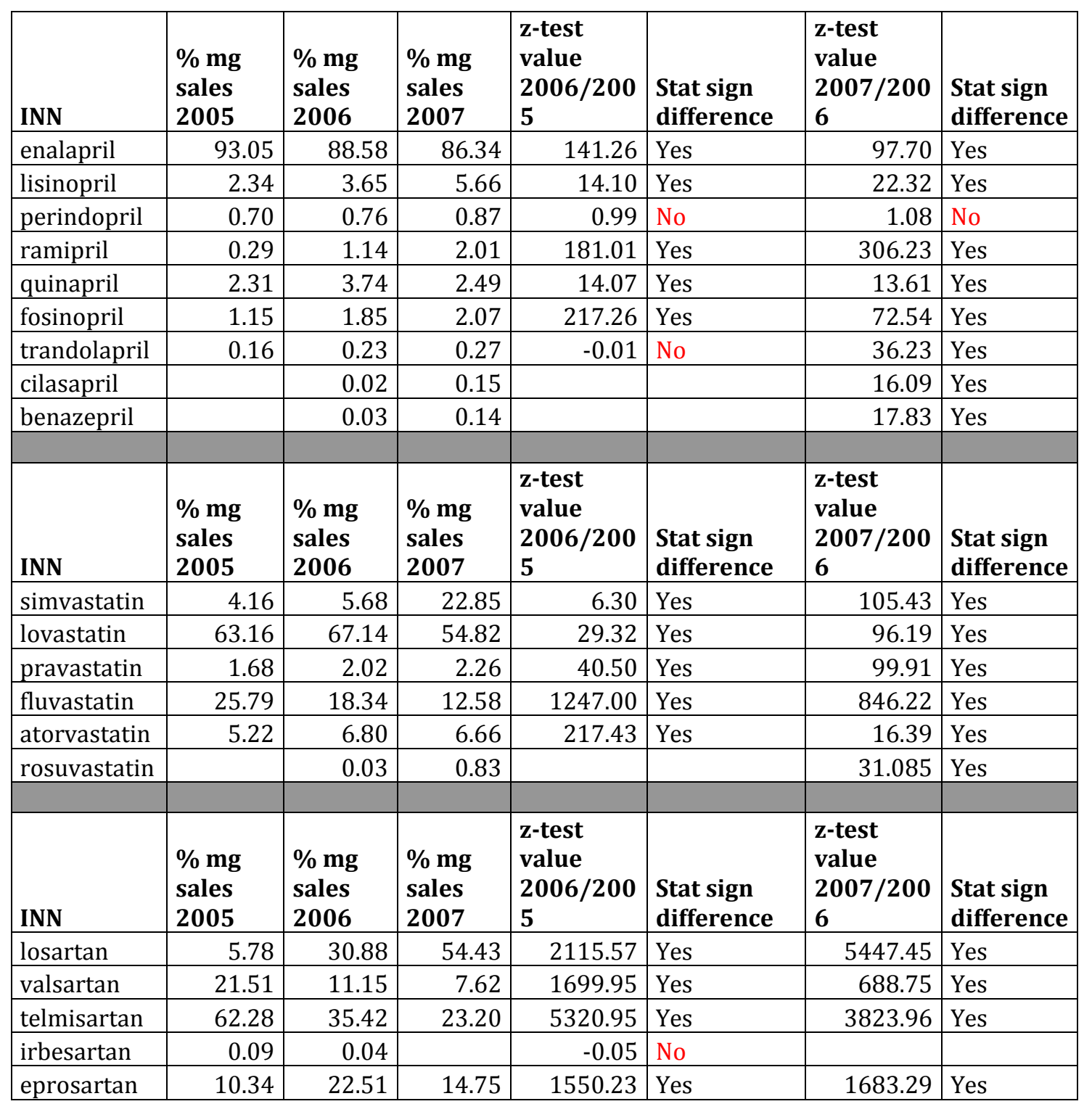


Table 3. Differences among the prices among the therapeutic competitors and among the years (Results of the two-way ANOVA analysis)

\begin{tabular}{|l|l|l|l|l|}
\hline $\begin{array}{l}\text { Therapeutic } \\
\text { group }\end{array}$ & $\begin{array}{l}\text { Prices differences } \\
\text { among the } \\
\text { therapeutic } \\
\text { competitors }\end{array}$ & $\begin{array}{l}\text { Statistical } \\
\text { significance }\end{array}$ & $\begin{array}{l}\text { Differences } \\
\text { among the prices } \\
\text { during the years }\end{array}$ & $\begin{array}{l}\text { Statistical } \\
\text { significance }\end{array}$ \\
\hline ACE inhibitors & $\mathrm{p}<0.05$ & Yes & $\mathrm{p}>0.05$ & No \\
\hline Statins & $\mathrm{p}<0.05$ & Yes & $\mathrm{p}>0.05$ & No \\
\hline Sartans & $\mathrm{p}<0.05$ & Yes & $\mathrm{p}>0.05$ & No \\
\hline
\end{tabular}


Table 4: Differences among INN prices during the years (one way ANOVA analysis)

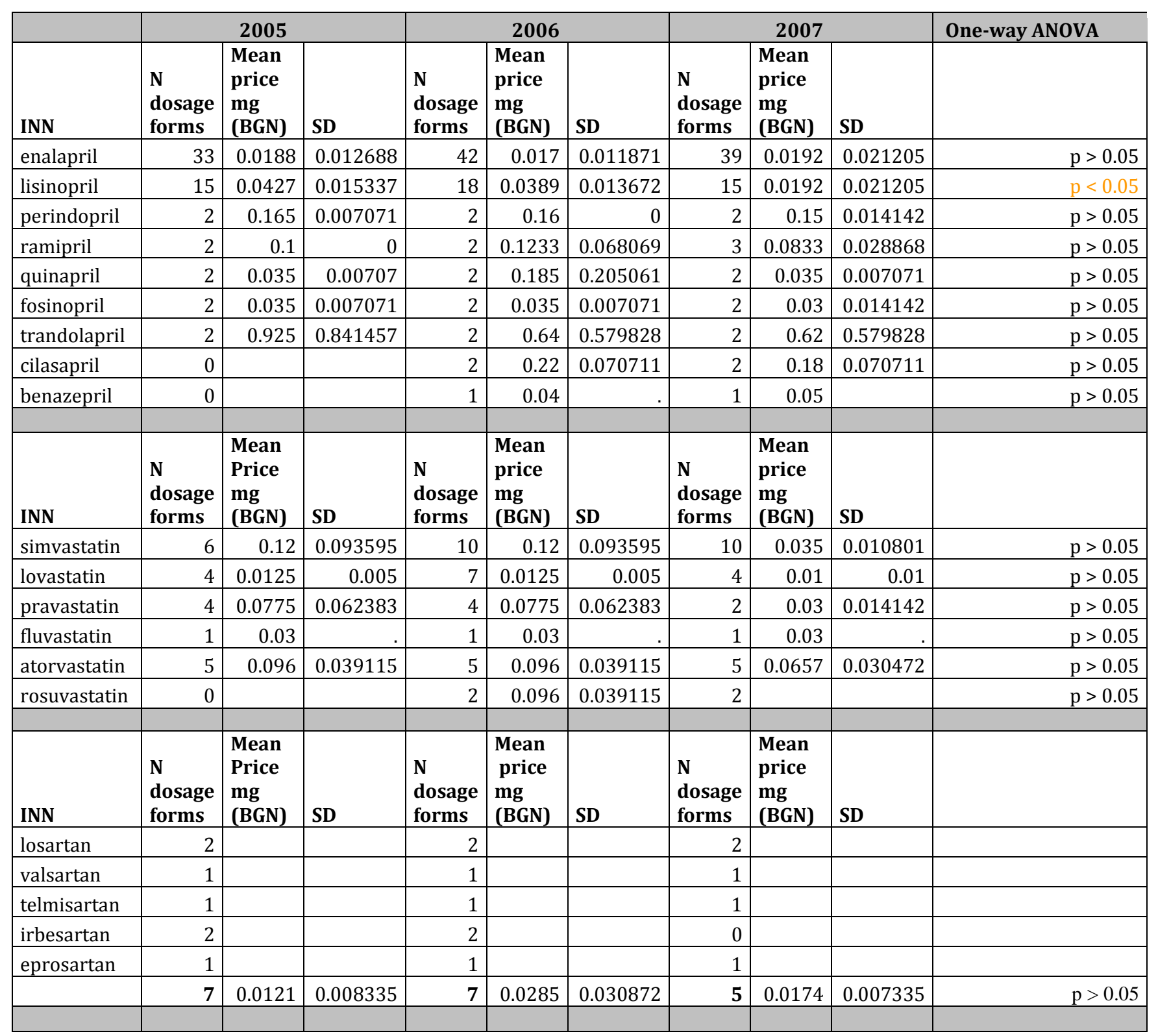




\begin{tabular}{|c|c|c|c|c|c|c|c|c|c|c|c|c|c|c|c|c|c|c|}
\hline INN & $\begin{array}{l}2005 \\
\text { sales } \\
\text { in kg } \\
\end{array}$ & $\begin{array}{l}\% \\
\text { mg } \\
\text { sale } \\
\text { s } \\
\end{array}$ & $\begin{array}{l}\mathbf{N} \\
\text { trade } \\
\text { names }\end{array}$ & $\begin{array}{l}\mathbf{N} \\
\text { dosage } \\
\text { forms }\end{array}$ & $\begin{array}{l}\text { Mean price } \\
\text { mg } 2005 \\
\text { BGN }\end{array}$ & SD & $\begin{array}{l}2006 \\
\text { sales } \\
\text { in kg } \\
\end{array}$ & \begin{tabular}{l|}
$\%$ \\
mg \\
sale \\
s \\
\end{tabular} & $\begin{array}{l}\mathrm{N} \\
\text { trade } \\
\text { names }\end{array}$ & $\begin{array}{l}\mathbf{N} \\
\text { dosage } \\
\text { sales } \\
\end{array}$ & $\begin{array}{l}\text { Mean } \\
\text { price mg } \\
2006 \text { BGN } \\
\end{array}$ & SD & $\begin{array}{l}2007 \\
\text { sales } \\
\text { in kg }\end{array}$ & $\begin{array}{l}\% \mathrm{mg} \\
\text { sales }\end{array}$ & $\begin{array}{l}\mathrm{N} \\
\text { trade } \\
\text { names }\end{array}$ & $\begin{array}{l}\mathrm{N} \\
\text { dosage } \\
\text { forms } \\
\end{array}$ & $\begin{array}{l}\text { Mean } \\
\text { price mg } \\
2007 \text { BGN } \\
\end{array}$ & SD \\
\hline enalapril & 1906796 & 93.1 & 8 & 33 & 0.0188 & 0.013 & 2287185 & 88.6 & 11 & 42 & 0.017 & 0.012 & 2362110 & 86.34 & 11 & 39 & \begin{tabular}{|l|l|}
0.01923 \\
\end{tabular} & \begin{tabular}{|l}
0.021 \\
\end{tabular} \\
\hline lisinopril & 47861 & 2.34 & 5 & 15 & 0.0427 & 0.02 & 94174 & 3.65 & 6 & 18 & 0.03889 & 0.014 & 154909 & 5.66 & 5 & 15 & 0.01923 & 0.021 \\
\hline perindopril & 14379 & 0.70 & 1 & 2 & 0.165 & 0.001 & 19729 & 0.76 & 1 & 2 & 0.16 & 0 & 23779 & 0.87 & 1 & 2 & 0.15 & 0.014 \\
\hline ramipril & 5881 & 0.29 & 1 & 2 & 0.1 & 0 & 29456 & 1.14 & 1 & 2 & 0.12333 & 0.068 & 55117 & 2.01 & 2 & 3 & 0.08333 & 0.029 \\
\hline quinapril & 47254 & 2.31 & 1 & 2 & 0.035 & 0.007 & 96471 & 3.74 & 1 & 2 & 0.185 & 0.205 & 68186 & 2.49 & 1 & 2 & 0.035 & 0.007 \\
\hline trandolapril & 3323 & 0.16 & 1 & 2 & 0.925 & 0.841 & 6061 & 0.23 & 1 & 2 & 0.64 & 0.580 & 7445 & 0.27 & 1 & 2 & 0.62 & 0.579 \\
\hline cilasapril & 0 & 0 & 0 & 0 & 0 & 0 & 554 & 0.02 & 1 & 2 & 0.22 & 0.071 & 3979 & 0.15 & 1 & 2 & 0.18 & 0.071 \\
\hline benazepril & 0 & 0 & 0 & 0 & 0 & 0 & 692 & 0.03 & 1 & 1 & 0.04 & & 3900 & 0.14 & 1 & 1 & 0.05 & \\
\hline SUMM & 2049113 & 100 & & & & & 2582084 & 100 & & & & & 2735978 & 100 & & & & \\
\hline INN & $\begin{array}{l}2005 \\
\text { sales } \\
\text { in } \mathrm{kg} \\
\end{array}$ & $\begin{array}{l}\% \\
\text { mg } \\
\text { sale } \\
\text { s } \\
\end{array}$ & $\begin{array}{l}\mathrm{N} \\
\text { trade } \\
\text { names }\end{array}$ & $\begin{array}{l}\mathrm{N} \\
\text { dosage } \\
\text { forms }\end{array}$ & $\begin{array}{l}\text { Mean price } \\
\text { mg } 2005\end{array}$ & SD & $\begin{array}{l}2006 \\
\text { sales } \\
\text { in kg } \\
\end{array}$ & $\begin{array}{l}\% \\
\text { mg } \\
\text { sale } \\
\text { s } \\
\end{array}$ & $\begin{array}{l}\mathrm{N} \\
\text { trade } \\
\text { names }\end{array}$ & \begin{tabular}{|l|} 
\\
dosage \\
forms
\end{tabular} & $\begin{array}{l}\text { Mean } \\
\text { price } \mathrm{mg} \\
2006 \mathrm{BGN} \\
\end{array}$ & SD & $\begin{array}{l}2007 \\
\text { sales } \\
\text { in kg } \\
\end{array}$ & $\begin{array}{l}\% \mathrm{mg} \\
\text { sales }\end{array}$ & $\begin{array}{l}\mathrm{N} \\
\text { trade } \\
\text { names } \\
\end{array}$ & \begin{tabular}{|l|}
$\mathrm{N}$ \\
dosage \\
forms \\
\end{tabular} & \begin{tabular}{|l|} 
Mean \\
price mg \\
2007 BGN \\
\end{tabular} & SD \\
\hline simvastatin & 13141 & 4.16 & 1 & 6 & 0.12 & 0.094 & 26304 & 5.68 & 3 & 10 & 0.06917 & 0.081 & 125098 & 22.85 & 3 & 10 & \begin{tabular}{|l|}
0.035 \\
\end{tabular} & \begin{tabular}{|l}
0.010 \\
\end{tabular} \\
\hline lovastatin & 199511 & 63.2 & 2 & 4 & 0.013 & 0.005 & 310970 & 67.2 & 4 & 7 & 0.01143 & 0.004 & 300126 & 54.82 & 2 & 4 & 0.01 & 0 \\
\hline pravastatin & 5302 & 1.68 & 2 & 4 & 0.078 & 0.062 & 9335 & 2.02 & 2 & 4 & 0.0925 & 0.064 & 12384 & 2.26 & 1 & 2 & 0.03 & 0.014 \\
\hline fluvastatin & 81453 & 25.8 & 1 & 1 & 0.03 & & 84939 & 18.3 & 1 & 1 & 0.03 & & 68862 & 12.58 & 1 & 1 & 0.03 & \\
\hline atorvastatin & 16487 & 5.22 & 2 & 5 & 0.096 & 0.039 & 31484 & 6.80 & 2 & 5 & 0.078 & 0.054 & 36445 & 6.66 & 2 & 5 & 0.06571 & 0.031 \\
\hline rosuvastatin & 0 & 0 & 0 & 0 & & & 157 & 0.03 & 1 & 2 & 0.16 & 0.028 & 4523 & 0.83 & 1 & 2 & 0.16 & \\
\hline SUMM & 315894 & 100 & & & & & 463189 & 100 & & & & & 547438 & 100 & & & & \\
\hline INN & $\begin{array}{l}2005 \\
\text { sales } \\
\text { in kg }\end{array}$ & $\begin{array}{l}\% \\
\text { mg } \\
\text { sale } \\
\text { s } \\
\end{array}$ & $\begin{array}{l}\mathrm{N} \\
\text { trade } \\
\text { names }\end{array}$ & $\begin{array}{l}\mathrm{N} \\
\text { dosage } \\
\text { forms }\end{array}$ & $\begin{array}{l}\text { Mean price } \\
\text { mg } 2005 \\
\text { BGN }\end{array}$ & SD & $\begin{array}{l}2006 \\
\text { sales } \\
\text { in kg }\end{array}$ & $\begin{array}{l}\% \\
\text { mg } \\
\text { sale } \\
\text { s } \\
\end{array}$ & $\begin{array}{l}\mathrm{N} \\
\text { trade } \\
\text { names }\end{array}$ & \begin{tabular}{|l|}
$\mathbf{N}$ \\
dosage \\
forms \\
\end{tabular} & $\begin{array}{l}\text { Mean } \\
\text { price mg } \\
2006 \text { BGN }\end{array}$ & SD & $\begin{array}{l}2007 \\
\text { sales } \\
\text { in kg }\end{array}$ & $\begin{array}{l}\% \\
\text { sales }\end{array}$ & $\begin{array}{l}\mathrm{N} \\
\text { trade } \\
\text { names }\end{array}$ & $\begin{array}{l}\mathrm{N} \\
\text { dosage } \\
\text { forms } \\
\end{array}$ & \begin{tabular}{|l} 
Mean \\
price mg \\
2007 BGN \\
\end{tabular} & SD \\
\hline losartan & 15715 & 5.78 & 2 & 2 & & & 196378 & 30.9 & 2 & 2 & & & 485894 & 54.43 & 2 & \begin{tabular}{|r|}
2 \\
\end{tabular} & & \\
\hline valsartan & 58464 & 21.5 & 1 & 1 & & & 70936 & 11.2 & 1 & 1 & & & 68051 & 7.62 & 1 & 1 & & \\
\hline telmisartan & 169261 & 62.3 & 1 & 1 & & & 225245 & 35.4 & 1 & 1 & & & 207122 & 23.20 & 1 & 1 & & \\
\hline irbesartan & 231 & 0.09 & 1 & 2 & & & 252 & 0.04 & 1 & 2 & & & 0 & & 0 & 0 & & \\
\hline eprosartan & 28090 & 10.3 & 1 & 1 & & & 143153 & 22.5 & 1 & 1 & & & 131695 & 14.75 & 1 & 1 & & \\
\hline
\end{tabular}


APPENDIX 1. Sales and prices values for the observed therapeutic groups and INNs of cardiovascular medicines in 2005,2006 , and 2007 
Figure 1: Relative market share of ACE inhibitors sales during 2005, 2006 and 2007.

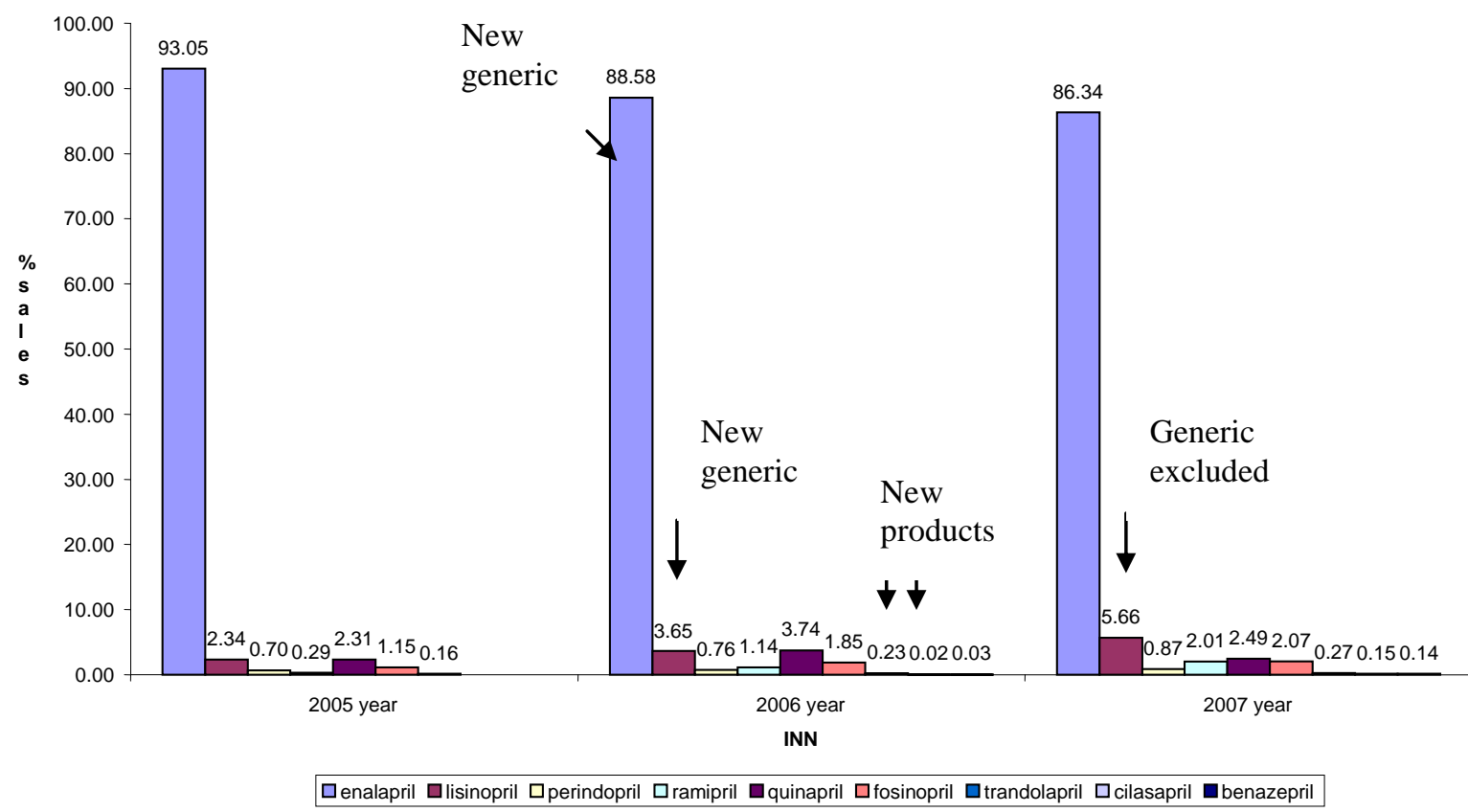


Figure 2: Relative market share of sartans sales during 2005, 2006 and 2007.

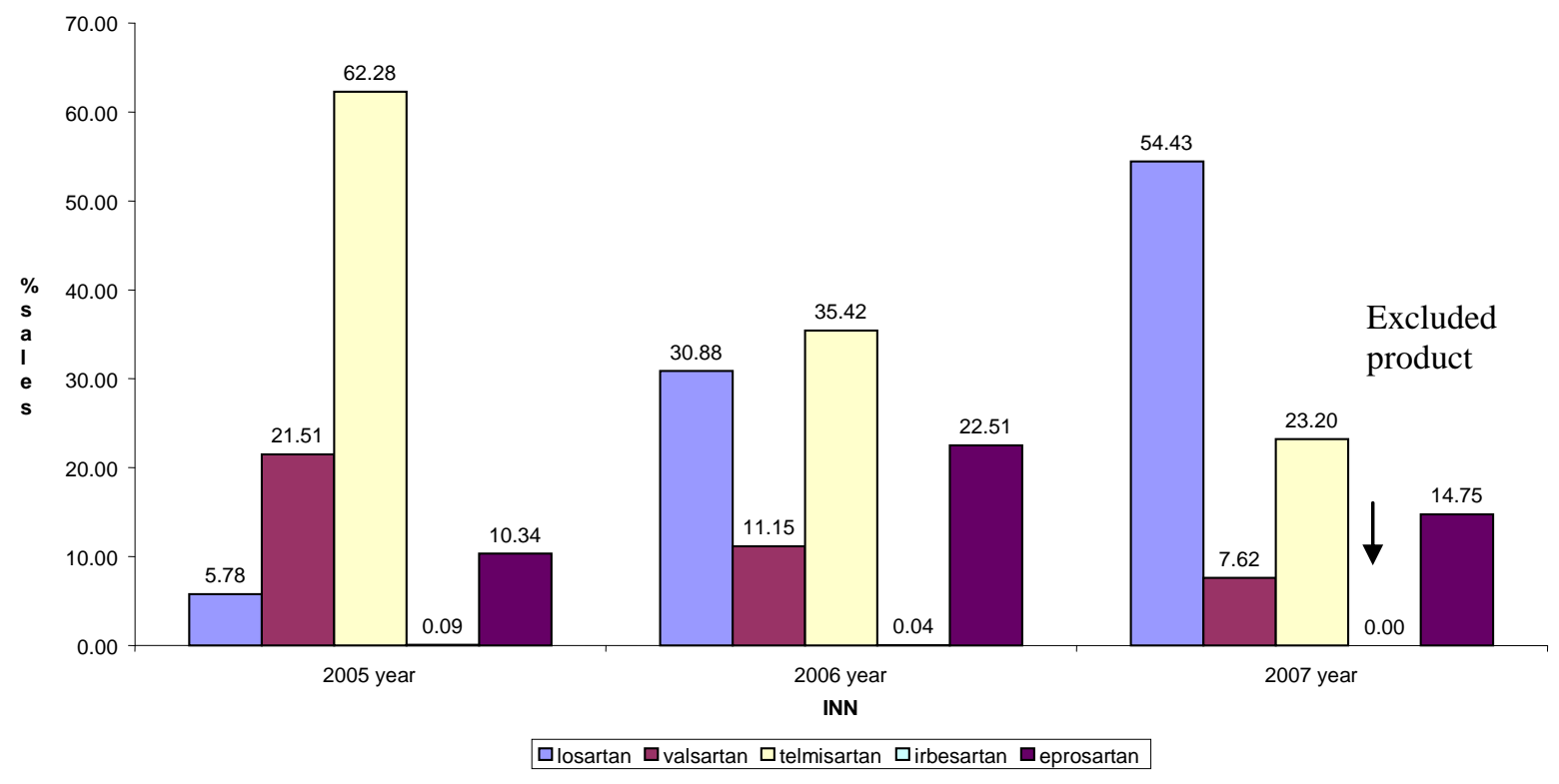


Figure 3: Relative market share of statins sales during 2005, 2006 and 2007.

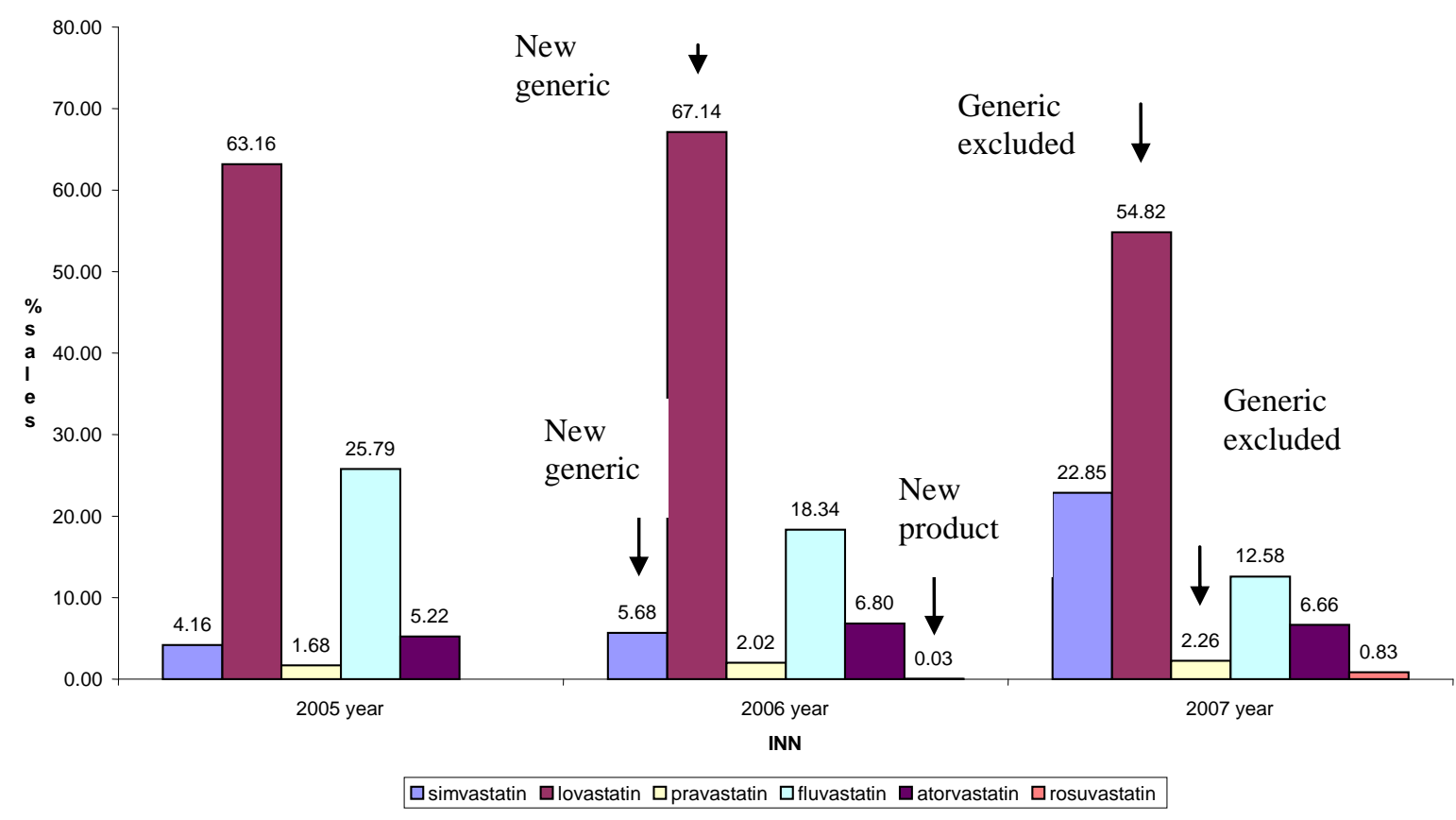

